\title{
PENTRU O ISTORIE A P.E.N. CLUB-ULUI ROMÂN: 3
}

\section{FOR A HISTORY OF THE ROMANIAN P.E.N. CLUB: 3}

\author{
Dan Horațiu POPESCU \\ Universitatea Creștină Partium, Oradea/ Partium Christian University, Oradea \\ e-mail: dhpopescu@yahoo.com
}

\begin{abstract}
The article, actually a would-be 3rd chapter of an intended piece of literary history, aims at retrieving, based on novel documents and on our own individual research, other defining moments in the history of the Romanian PEN Club, i.e. the activity with a view to consolidation in the years right after WWI. The recuperated sequences are integrated within the enlarged historical, political, social and cultural context of the time. The figure of Marcu Beza, the Romanian Anglicist and diplomat in London in the 1920s, is in close-up, together with that of Emanoil Bucuța, the Secretary of the Romanian P.E.N in its first decade of activity, due to their determination in engaging Romanian writers in the emergent circuit of democratic values specific to western societies.
\end{abstract}

Keywords: World War I; Romanian P.E.N. Club; Marcu Beza; Emanoil Bucuța; Queen Mary; Karel Čapek.

\section{Introducere: Frăția condeiului}

Într-un articol publicat în 2017, în Observatorul Cultural, Magda Cârneci, președinta în exercițiu la acel moment a P.E.N. Club-ului Român, își exprima, în contextul aniversării a 95 de ani de la înființarea acestuia, uimirea şi mândria că evenimentul avusese loc la numai un an de la crearea P.E.N Club-ului de la Londra. Deci, în 1922, conform informațiilor din secțiunea „Our History” de pe site-ul www.pen-international.org. Dar tot în cuprinsul aceluiași articol, autoarea constata că ,,în România, există încă percepția că P.E.N. Club-ul local s-ar fi creat în 1923, atunci când, probabil, el a devenit activ cu adevărat" (Cârneci, 2017)

Surprinzător este faptul că această percepție dăinuie de multe decenii, începând cu personalități direct angajate în procesul de constituire a filialei din țara noastră. Astfel, Emanoil Bucuța sau ,ajutorul de secretar”, cum însuși se minimaliza, al P.E.N. Club-ului Român în acea perioadă $\breve{1}^{1}$, părea destul de sigur pe sine atunci când, în articolul de bilanț aniversar din Boabe

\footnotetext{
${ }^{1} \mathrm{Nu}$ am avut acces la informații certe în legătură cu anul în care Bucuța a devenit ajutor de secretar, 1923 sau 1924, dar mai târziu a ajuns secretar plin, funcție pe care a exercitat-o până în 1932.
} 
de Grâu, nr. 5 din 1934, afirma că 1923 este anul în care încep în România discuțiile despre P.E.N. Club.

Documentele oficiale însă îl contrazic. Printr-un concurs de împrejurări am intrat în posesia corespondenței scriitorilor români, începând cu Marcu Beza, cu cei din conducerea P.E.N Internațional, și am putut să lămuresc acest aspect (Popescu, 2019: 74). Nu la fel de norocos am fost în ce privește alte surse de informare. Practic, nu există o arhivă a P.E.N. Club-ului Român. Există un registru, din care s-au păstrat câteva foi, aflat în posesia familiei Cioculescu, rămas de la Radu Cioculescu, secretar al filialei din România începând cu anul 1932. Și mai există două dosare, cu documente de pe la mijlocul anilor '70, păstrate la Uniunea Scriitorilor din România. Ele vor constitui, sper, premisele unor studii viitoare, coroborate desigur cu corespondența mai sus menționată.

Articolul de față se oprește la anul 1924 pentru că are în vedere primele ieșiri în lume, la nivel internațional, ale reprezentanților P.E.N. Clubului Român. Așa cum am dovedit-o (Popescu, 2019: 74), secțiunea din România se înființase în 1922, dar le-a luat mai bine de un an scriitorilor români ca să tenteze a subscrie la modelul furnizat de scriitorii britanici. E adevărat că, pe hârtie, respectiv în scrisorile trimise de Marcu Beza doamnei Dawson Scott, întemeietoarea ordinului scriitoricesc, dar și fiicei sale, secretara executivă, Marjorie Scott Watts, se regăseau nume și funcții, precum I. Al. Brătescu-Voinești ca președinte și Vasile Pârvan ca secretar.

Probabil că, sesizând importanța momentului și obișnuit cu pescuitul în apele tulburate ale diplomației, mai ales după război, Marcu Beza și-a dorit ca să figureze și România, măcar la nivel scriptic, în dosarele organizației. Dar abia după întâlnirea festivă de la Londra, din 1 mai 1923, cu delegați din toată lumea, abia în noiembrie același an, ,alergând din om în om” (Bucuța, 1934: 284) diplomatul și scriitorul român a reușit să își motiveze confrații spre a se aduna în sala Hotelului Bulevard din București, de la intersecția Căii Victoriei cu Bulevardul Elisabeta. În articolul aniversar nu sunt însă menționate decât numele președintelui și al secretarului, precum și cel al lui Victor Ion Popa, responsabil, cu caricaturile sale, de imortalizarea momentului.

1923 ar fi deci anul în care se intețesc în România discuțiile de până atunci.

„Între pereți și stâlpi de marmură s'au adunat întăia ${ }^{2}$ oară membrii centrului român ai clubului PEN, scria același Emanoil Bucuța, la o masă care trebue să aibă totdeauna ca arhetip Ospățul lui Plato cu ghirlandele de trandafiri ale gândirii.” (Bucuța, 1934: 285).

${ }^{2}$ Am respectat grafia din documentele și articolele vremii. 
În opinia lui Bucuța, cei prezenți nu erau pe deplin conștienți de semnificația evenimentului - „Cei mai mulți nu știau [...] de ce veniseră” (Bucuța, 1934: 286). Nici interesele de breaslă și nici vreun festivism anume nu păreau să fi fost suficient de mobilizatoare. El chiar își amintește, referindu-se la articolul din Ideea Europeană în care relatase despre întâlnire în 1923, și de sentimentul de efort pe care îl încercase - ,a trebuit să îmbrac un stil de mare sărbătoare ca să nimeresc tonul și speranțele serii” (Bucuța 1934: 285).

Răceala inițială, care poate că explică de ce unii dintre cei de faţă la această primă agapă nu s-au mai regăsit ulterior pe drumuri comune, s-a risipit treptat. Ideea care a reușit totuși să le capteze atenția, așa cum le-a fost prezentată ea de către organizatori, era aceea că „toți purtătorii de condeiu cu năzuință de artă sunt legați între ei prin aceleași ținte, dorite și urmărite mai presus de orice ispite și piedici (Bucuța, 1934: 286), recte dincolo de aventura, îndeobște solitară, de navigare în jurul lumilor lirice sau ficționale și „,că această comunitate, ca să fie activă, trebue să ajungă prin punere în contact la simțul propriei solidarități.” (Bucuța, 1934: 286)

\section{Dificultățile de organizare și structurare}

Speranţa în această frăţie a condeiului este subliniată și într-un scurt articol, pe o singură coloană, decupat dintr-un ziar din epocă, intitulat simplu P.E.N., al cărui autor își dă doar inițialele, L. R. Sursa articolului, pe care 1am găsit în Arhiva Marcu Beza de la Muzeul Colecțiilor de Artă din București, din păcate, nu am reușit să o identific. Este invocat, la început, Goethe $\mathrm{cu}$ considerațiile sale despre caracterul național, respectiv internațional, al operei unui scriitor. Autorul articolului taxează acele mărunțișuri catalizatoare - „Și când au încercat să se adune [scriitorii] tot mânați de mărunțișuri au făcut-o: curente de artă, simpatii politice, scopuri exterioare materiale..." (Arhiva Marcu Beza, 3671) - care oricum ar fi împiedicat, de secole, buna comunicare între artiști.

În pofida unor astfel de critici, modelul P.E.N. Club-ului londonez este introdus și prezentat ca funcțional, dar la intervale regulate, în limitele codului respectabilității britanice - „nu pentru totdeauna: numai pentru câteva ore pe săptămână sau pe lună, atâta cât durează o masă". (Arhiva Marcu Beza, 3671) Paragrafului nu îi lipsește o notă de naivitate - „La poarta clubului fiecare membru trebuie să-și lase afară năzuințele politice, sociale, economice" (Arhiva Marcu Beza, 3671); el se încheie chiar cu proiecția unei Castalii în miniatură, cu accente dâmbovițene - „Clubul, astfel, devine o familie simpatică în sânul căreia toți se simt bine, unde arta e acasă și de unde pot răsări imbolduri noui de muncă." (Arhiva Marcu Beza, 3671)

Ceea ce diferă între cele două articole, cel aniversar al lui Bucuța, din 1934, și cel al lui L. R. din 1923, este perspectiva asupra faptelor. În cazul lui Bucuța, ea pare o oglindă care mărește, rezultat poate al memoriei afective - 
„acea întâie ședință a PEN Clubului român, căreia până astăzi n'a mai putut să-i stea o a doua, la fel de măreață, alături” (Bucuța, 1934: 285). La celălalt autor, impresia cititorului e de notă de constatare, nu lipsită însă de optimism - „Deocamdată vre-o douăzeci de scriitori s'au adunat, s'au sfătuit, au aclamat doi președinți, un secretar și un casier.” (Arhiva Marcu Beza, 3671).

Cei doi autori aveau oare în vedere aceeași întâlnire? „Măreață” și cu doar douăzeci de sciitori? Numai douăzeci și totuşi doi președinți? „Erau scriitori bătrâni și scriitori tineri, scriitori vechi și scriitori noui” (Bucuța, 1934: 286), scria Bucuța, care parcă multiplică, de la o frază la alta, în jocuri speculare, numărul invitaților - „Cei mai mulți nu știau cine-i chemase...”, constata el, înregistrând și ,răceala dela început între grupele în picioare și răslețe, vorbind încet, dinaintea recilor oglinzi.” (Bucuța, 1934: 286).

Articolul decupat și semnat L.R. - să fie vorba despre Liviu Rebreanu? - și scris în limba română, pare să fi fost arhivat în lumea de limbă engleză într-un context diplomatic. El are o notă în partea din stânga sus, în care este menționată proveniența și data - „From Romania (16th November 1923)". Scrupulozitatea consulului român de la Londra, a celui obișnuit să lucreze cu documente oficiale, îl va fi determinat să păstreze această dovadă a eforturilor sale de a crea capete de pod în lumea nu doar diplomatică, ci și în cea culturală, britanică.

Cât despre lecția englezilor - cei „,deprinși cu micile înjghebări, aproape familiare la început, din care mai târziu au scos regule de viață sau imperii” (Bucuța 1934: 284), după cum pertinent îi caracteriza secretarul P.E.N. Club-ului Român -, ea a prins destul de greu în dulcele areal carpatobalcanic. În literatură, acesta din urmă, pe de o parte era toropit de cadența sămănătoristă, iar pe de altă parte se învolbura animat de frisoane proustiene și gidiene.

Nu lipseau nici frisoanele politice, după cum constata Bucuța într-o scrisoare către Marcu Beza din 26 ianuarie 1924. După ce își exprimă satisfacția pentru că „Am început în sfârșit lucrul pentru P.E.N. Club” cu sărbătorirea lui Brătescu-Voinești, unul din cei doi președinți în exercițiu, Bucuța i se plânge lui Beza că nu reușește să intre în posesia unui statut al organizației. Persoana care ar fi trebuit să rezolve problema era Dragoș Protopopescu, secretarul cu normă întreagă, ,înscris cu declarație de principii în regulă la țărăniști." (Arhiva Marcu Beza 3714)

Cum această ultimă formulare încheie brusc scrisoarea, nu am putut să îmi dau seama dacă ceea ce îl deranja de fapt pe Emanoil Bucuța era orientarea politică a tânărului anglist sau angajarea acestuia într-un demers care în mod sigur urma să îi afecteze timpul de lucru necesar derulării activităților P.E.N. Deși iniţial persoana cu cele mai puține atribuții și responsabilități, Bucuța s-a dovedit a fi cel mai tenace și longeviv din echipă, 
cu intenții din ce în ce mai ferm conturate - „Vom continua cu mesele, dar și cu un program mai... cultural" (Arhiva Marcu Beza, 3714).

Dragoș Protopopescu era însă din ce în ce mai greu de găsit, cariera universitară constituindu-se într-o adăugită provocare - „Dragoș (...), precât știu, se duce deadreptul la Cernăuți, unde are o catedră de suplinit.” (Arhiva Marcu Beza, 3716) -, scria același Bucuța la 19 iulie 1924, subminând speranțele lui Beza în ce privește viitorul activităţii de secretar P.E.N. a lui Protopopescu. Drept pentru care poate că nu trebuie să surprindă, la doar o jumătate de an de la scrisoarea citată anterior, afirmația, cu caracter categoric și chiar alarmant, cum că - „P.E.N. Clubul Român, în schimb, nu există." (Arhiva Marcu Beza, 3716).

Și totuși surprinzătoare, cu atât mai mult cu cât, în paragraful de dinaintea acestei sumbre constatări, Bucuța părea mulțumit de materialul informativ apărut în Ideea Europeană, despre ,ziua P.E.N. Clubului de la Washington", care avusese loc în mai. Fusese un articol mai lung, amputat din motive de ordin tehnic, în care „,a trebuit să intre și clișeul.”, recte o caricatură care ,a ieșit, și așa micșorată, destul de expresivă!” (Arhiva Marcu Beza, 3716).

Ce altceva stârnise atunci nemulțumirea, profundă, a ajutorului de secretar P.E.N. din Bucarest? La scară internaţională, România era rezonabil reprezentată, având un loc pe care părea să-l merite, căci figura ca a zecea țară din lume unde luase ființă un centru P.E.N.. Acasă, în schimb, Emanoil Bucuța nu o dată se simțea neputincios, după cum îi mărturisea lui Marcu Beza, mai ales „din pricina "grangurilor”, cum s'ar zice la noi într'un stil periferic, dela conducerea lui de azi." (Arhiva Marcu Beza 3716). Parțial, aceste nemulțumiri sunt reflectate și în comentariile, din articolul aniversar din 1934, la adresa lui Nicolae Iorga, primul român membru de onoare al P.E.N. Club-ului International, și a lui Vasile Pârvan, ajuns co-președinte al filialei românești, care nu ar fi realizat semnificația proiectului inițiat de britanici.

O lipsă de colaborare și coordonare, de racordare la tensiunea intelectuală și artistică a epocii, era vizibilă și în absența reacției la banchetul din 1924 din capitala Marii Britanii - „Vizita Reginei la ședința de onoare din Londra aici n'a avut niciun răsunet. (Arhiva Marcu Beza, 3716). Bucuța fusese prezent și chiar descrisese „evenimentul amănunțit pentru gazete”, într-o scrisoare, cu destin fatalmente mioritic, pierdută. Nici Regina, dar nici președinții în exercițiu ai centrului - aici erau așteptările cele mai mari -, nuși îngăduiseră dispoziția sau răgazul să schimbe impresii despre întâlnire sau despre „, - te pomenești! - angajamente luate față de colegii englezi.” (Arhiva Marcu Beza, 3716). Întrebarea care închide paragraful dedicat problemelor P.E.N. denotă pierderea răbdării precum și revolta condeierului - „Nu trebuie făcut ceva... pentru ca P.E.N. Clubul Român, mai ales după ziua dela 
Washington și după perspectivele de generală reorganizare, să înceapă a trăi în adevăr?" (Arhiva Marcu Beza, 3716).

\section{Diligențele în lumea literară internațională. Congresul din SUA}

La celălalt capăt al continentului, uneori chiar la capătul lumii, Marcu Beza își continua diligențele în vederea ancorării românești în vâltoarea mișcărilor din lumea literară de după Primul Război Mondial. Fusese singurul reprezentant al României la congresul din Statele Unite, dat fiind că „starea leului împiedica alte plecări”, fapt subliniat de Emanoil Bucuța întruna din cele ce el numea „notițe informative”, publicate, de câte ori avea ocazia, în Ideea Europeană. Așa cum rezultă dintr-o asemenea „notiță”, publicată în iulie 1924, precum și din scrisoarea, mai sus menționată, a lui Bucuța către Beza, din aceeași lună, întâlnirea ar fi avut loc la Washington. Arhivele P.E.N. International indică însă drept cadru de desfăşurare a Congresului, între 13 și 15 mai, New York-ul.

Co-președintele Vasile Pârvan o informase pe Marjorie Scott, într-o scrisoare din 4 aprilie 1924, că pe 10 mai același an urma să fie la Bruxelles, ca delegat al României la întâlnirea anuală a Union Académique International. $\mathrm{Cu}$ această ocazie promitea să viziteze centrul P.E.N. din Belgia și să o țină la curent cu noutăţile. Era, într-un fel, o scuză pentru declinarea invitației Clubului P.E.N. de la New York, unde - „Trebuie să mărturisesc, ne este imposibil să mergem" (Pârvan, Arhiva P.E.N. International). Totodată, o asigura că nu vor mai exista nici un fel de disfuncționalități de comunicare, întrucât secretarul centrului român, Dragoș Protopopescu, deși proaspăt cadru didactic la ,una din universitățile noastre din provincie" (Pârvan, Arhiva P.E.N. International), avea toate contactele necesare pentru a-și exercita atribuțiile.

„Pe la jumătatea lunii florilor s'au adunat la Washington scriitorii din toate țările” (Bucuța, 1934: 287), așa își începe ,ajutorul de secretar” acea „notiță” bazată pe informațiile furnizate de Beza, pe care o reproducea parțial în articolul aniversar, un deceniu mai târziu. Washington sau New York? Încă o mostră din acel tip de ambiguitate care plasează parcă începuturile (și nu doar ale) P.E.N. Club-ului Român într-un cadru fabulos. Ceea ce într-un fel și erau anii 1920: pentru Statele Unite, epoca prohibiției, epoca jazz-ului, epoca nesfârșitelor petreceri cu personaje fitzgeraldiene; iar pentru Europa, epoca sărbătorii de neuitat a Parisului, a unei capitale culturale în care membrii unor generații pierdute în timpul Primului Război Mondial urmau un trend ascendent de recuperare.

Că a fost la Washington sau la New York, sau în ambele locuri, o întâlnire de lucru și o alta festivă, adunarea din 1924 era una cu o înțelegere mai nuanțată a contextului postbelic, mai flexibilă, în cazul României, decât atitudinea profund anti-germană manifestată de Nicolae Iorga cu un an 
înainte ${ }^{3}$. „Scriitorii apăreau, lumii și lor, ca o putere” (Bucuța, 1934: 287), continuă Bucuța, într-o notă plină de speranță (sau de auto-iluzionare?) „Scutieri ai idealului, se întâlneau pentru o pace, mai adâncă decât aceea a tratatelor.” (Bucuța, 1934: 287). În consecință, hotărâri importante fuseseră adoptate, respectiv formarea unui centru internațional la Londra, precum și obligația de a trimite cu regularitate către acesta, din partea filialelor, a unor rapoarte de activitate care să constituie baza unei dări de seamă anuale.

Că New York-ul a fost unul dintre orașele care a găzduit evenimentele P.E.N. rezultă din trecerea bruscă, în cadrul articolului, de la menționarea deciziilor la augmentarea lor în cadrul unei „cine strălucite dela Hotelul Pennsylvania", hotel emblematic pentru metropola de pe Coasta de Est. Ceea ce atunci ar fi fost perceput ca un semn de cosmopolitism, ar fi astăzi tradus ca multiculturalism, date fiind ,supa mexicană, țelina belgiană, ridichile germane, măslinile spaniole, peștele american, cartofii, firește, cehoslovaci, sosul la sparanghel olandez, friptura franceză.” (Bucuța, 1934: 288).

$\mathrm{Cu}$ componenta de socializare activată la capătul unor, presupunem, intense dezbateri, întrebarea care urmează acestei etalări de ingrediente fine dining, e o marcă a unui act original de transculturalism - „Cu ce se putea încheia mai bine acest ospăț decât cu Café Roumania, care era probabil cafea turcească?" (Bucuța 1934: 288). Iar citatul amplu din cuvântarea lui Marcu Beza reiterează ideea, adăugând însă o notă de malițiozitate, dat fiind că evenimentul se derula, așa cum am și arătat deja, în plină epocă a prohibiției:

„Vă amintiţi în Pantagruel al lui Rabelais, acea carte caracteristică pentru larga vedere a Renașterii, cum călătorii spre templul lui Bambuc ating în sfârșit mult căutatul oraș şi cum marea preoteasă le dă să bea vin, care, fiind din aceeaș fântână, pare totuș fiecăruia dintr'înșii cu totul deosebit. De mi s'ar făgădui ${ }^{4}$ să folosesc aci o comparație din lumea oprită a băuturii, aș zice că literatura este ca vinul din templul lui Bambuc. Are fiecare țară aroma ei proprie, pe care suntem încântați s-o gustăm" (Bucuța 1934: 288).

O caricatură de la eveniment, aparținând lui Wyncie King, publicată în materialul din Ideea Europeană din 1924, a fost și ea reprodusă în articolul aniversar din 1934. În 1924 deci, în preajma lui Marcu Beza, la dineul de la Washington, conform textului însoțitor, se aflau: Hamlin Garland, romancier al Midwestului american, altfel interesat de fenomenele paranormale; Americo Castro, controversat istoric al culturii, filolog și viitor ambasador, în 1931, al Republicii Spaniole în Germania; Olga Ott, autoare daneză de

\footnotetext{
${ }^{3}$ Congresul a avut loc la Londra, la 1 mai 1923. A se vedea articolul meu „Pentru o istorie a P.E.N. Club-ului Român: 2”, din Analele Universității Oradea, Fascicula Filologie Română, 2019.

${ }^{4}$ Probabil o eroare de tipar, logic ar fi fost ,îngădui".
} 
literatură pentru copii și tineret; Robert Frost, care nu are nevoie de nici o prezentare pentru degustătorii de literatură deopotrivă tradiționalistă și haute couture; Fannie Hurst, cea mai bine plătită prozatoare americană a anilor 1920, recuperată de mișcarea feministă la începutul anilor 2000; Arthur Davison Ficke, sonetist și expert în artă japoneză, un Fernando Pessoa al literelor americane, dar la o scară mai redusă, promotor al ficționalei mișcări poetice spectriste.

Tot în același cadru: May Sinclair, autoare și sufragetă britanică creditată ca fiind cea dintâi care a utilizat expresia fluxul conștiinței $i^{5}$; Mary Austin, autoare americană de non-ficțiune, feministă și luptătoare pentru drepturile băștinașilor și ale hispanicilor; tot american, Alexander Black, fotograf și precursor, prin producțiile sale mixte, al filmului ca gen și artă; Jules Romains, romancier francez, promotor al unanimismului, viitor președinte al P.E.N. Internaţional ${ }^{6}$ și viitor bun amic al lui Marcu Beza; mexicanul Octavio Barreda - caricatura prezintă un bărbat de vârstă medie, nu chiar suplu, cu început de chelie. Cel identificat de noi pe internet prezintă începutul de chelie, dar este slab, ar fi avut 27 de ani în 1924 și apare ca Octavio G. Barreda, poet mexican și traducător al lui T.S. Eliot, D.H. Lawrence și Saint-John Perse; și, în fine, „d-na Olga Knippev-Cekova"7, rafinata actriță rusă, aflată acolo în calitate de, cel puțin, văduvă a marelui Cehov.

Oricum, la 1 decembrie 1924, scriind, din provincia în care rezida, Secretarei Centrului P.E.N. din Londra, Dragoș Protopopescu confirma primirea ultimei misive din partea acesteia. El era împuternicit să răspundă că și centrul român își exprima atașamentul deplin față de toate sugestiile și propunerile făcute la întâlnirea de la Washington. „Să-mi fie de asemenea îngăduit să adaug", continua el în dulcele stil ceremonios al acelei Golden Age interbelice, ,că P.E.N. Club-ul Român se va strădui, din toate micile sale puteri, să le promoveze și să le pună în practică." (Protopopescu, Arhiva P.E.N. International)

\section{Londra}

Diligențele în lumea literară internațională. Banchetul de la

Ceea ce avea să rateze Marcu Beza, „lipsind tocmai pe acea vreme din Londra" (Bucuța, 1934: 288), a fost ședința specială a P.E.N. Club-ului englez la care Regina Maria a României, la ,întâia [ei] călătorie prin Europa de după războiu" (Bucuța, 1934: 289), avea să fie în prim-plan. Cuplul regal

\footnotetext{
5 Într-un articol despre seria de romane Pilgrimage/Pelerinaj, de Dorothy Richardson, în The Egoist/Egoistul, numărul din aprilie 1918.

${ }^{6}$ Între 1936 și 1941.

${ }^{7}$ Am redat numele așa cum apare el în caricatura reprodusă în Boabe de Grâu. Corect se pare că ar fî fost Knipper, nu Knippev, actrița provenind dintr-o familie de origine germano-austriacă.
} 
român vizita Londra și în contextul Expoziției Imperiului Britanic, deschisă pe 23 aprilie 1924, de ziua sfântului patron al Angliei. Era una dintre consacratele, deja, expoziții internaționale, dar printre cele foarte puține care, încă din titulatură, subliniau dimensiunea colonială ${ }^{8}$. Dar ,mai ales la expozițiile coloniale și imperiale, unde istoria și geografia le confirmau națiunilor identitatea, rasa și modernitatea" (Lawn, 2009: 10), efectele expozițiilor ca site-uri educaţionale erau gestionate în mod corespunzător. O lecție pe care România putea să o învețe și să o și transpună în bună practică.

La 30 aprilie, într-o scrisoare cu antetul P.E.N. CLUB/ ASOCIAȚIE INTERNAȚIONALĂ A POEȚILOR, ESSAYIȘTILOR ȘI NUVELIȘTILOR, Vasile Pârvan îi aducea la cunoștință lui Marjorie Scott că sosise la Londra ,unul dintre cei mai activi membri ai centrului nostru, Dl. Emanoil Bucuța, un foarte distins eseist, poet și editor" (Pârvan, Arhiva P.E.N. International). Misiunea acestuia din urmă era să organizeze în metropola de pe malurile Tamisei o mică expoziție etnografică și de artă românească, întru folosul „multor britanici, care vor veni la Expoziția Imperiului”. (Pârvan, Arhiva P.E.N. International) În fond, ,rolul expozițiilor mondiale din secolul al nouăsprezecelea și de la începuturile secolului douăzeci era să confirme relația dintre statul-națiune și modernitate" (Lawn, 2009: 8) Iar România, proaspăt ieșită și întregită din Primul Război Mondial, avea nevoie de exact o astfel de manifestare.

Așa se explică faptul că ,ajutorul de secretar” a ajuns la Londra și a putut să asiste la acea ședință specială a P.E.N. Club-ului englez, dar nu din mai ci din 3 iunie 1924 (Bradbook, 1960: 61) Erau de fapt întâlniri lunare, aceste ședințe cu invitați. Sărbătorită de peste 250 de oameni de litere ca „Președintă de onoare a PENClubului român”, regina Maria avea să-și amintească, zece ani mai târziu, într-o discuție cu Bucuța, de „englezeasca tăioasă... și de privirea albastră îndrăsneață, pe care o plimba peste acea lume ascuțită” (Bucuța, 1934: 289), celălalt invitat special al zilei, conform tradiţiei P.E.N., scriitorul „Carol Ciapek”.9

Autorul ceh se afla la prima și singura lui vizită în Anglia. După o serie de ezitări, generate atât de felul său modest și rezervat de a fi, cât și de un eveniment tragic în familie, moartea mamei sale (Bradbook, 1960: 62), îi scria amicului său de la Londra, profesorul Vočadlo, că trebuie să accepte invitația la hotelul asigurat de P.E.N. Club, dar că nu dorea să stea acolo mai mult de perioada din preajma prânzului festiv. Își ruga de asemenea amicul să ii facă rost, pentru alte cinci zile, de o cameră la un hotel mic, dar decent, admițând însă că așa ceva ,ar putea fi greu de găsit pe timpul expoziției." (Bradbrook ,1960: 62) Se întreba dacă cinci săptămâni i-ar fi de ajuns ca să

\footnotetext{
${ }^{8}$ Mai fuseseră: Amsterdam 1883 - International Koloniale en Untvoerhandel Tentoonstellung; Londra 1886 - Colonial and Indian Exhibition; tot Londra, 1911 - Festival of Empire.

${ }^{9}$ Conform grafiei din articolul lui Emanoil Bucuța din Boabe de Grâu.
} 
vadă ce era de văzut în Anglia și își dorea să-i întâlnească pe Shaw, Wells și Chesterton.

Čapek s-a bucrat de o primire grandioasă din partea membrilor P.E.N. și a celorlalți aproximativ 100 de invitaţi de la restaurantul Gatti, printre care se numărau Galsworthy, V. Sackville-West, Rebecca West etc. (Bradbook, 1960: 63) Din păcate, reporterii de la The Times, interesați mai mult de rochia Reginei Maria, 1-au cam ignorat pe Čapek. Discursul său a fost însă reprodus de prestigiosul cotidian și, așa cum își amintea Marjorie Scott, se bucurase de un succes mai mare decât imaginea reginei, a cărei întârziere de o oră pusese pe jar asistența.

250 de invitați sau 100? Care ar fi opțiunea credibilă? Generozitatea „ajutorului de secretar” al P.E.N. Club-ului român sau parcimonia viitorului președinte al P.E.N. Club-ului cehoslovac? ${ }^{10}$ „Dacă voi găsi destulă înțelegere de inimă să schițez și eu câteva impresii engleze", se autoîncuraja Bucuța în scrisoarea către Beza din iulie 1924, „negreșit că voiu scrie despre cea mai frumoasă adunare de scriitori pe care am văzut-o, drept o coroană regală împletită cu crini." (Bucuța, 1934: 289)

Alte probleme, de această dată de cronologie, apar în articolul aniversar din 1934, plasând din nou istoria (nu doar a) P.E,N. Club-ului român sub o aură mitică. „Atunci, în Mai 1924, în capitala Angliei fără ploi ca niciodată" (Bucuța, 1934: 288), deci nu în iunie, cum rezulta din articolul despre Čapek menționat mai sus, „în soarele unei amiezi primăvăratice” (Bucuța, 1934: 289), Regina Maria s-a așezat „la o masă pătrată, la capătul meselor lungi”, însoțită de „John Galsworthy și o curte de mari scriitori”" (Bucuța, 1934: 289), printre care și celălalt protagonist al evenimentului, autorul cehoslovac.

Evenimentul, o spun foarte clar documentele din Arhiva P.E.N. International, a avut loc în 3 iunie 1924. Conform notei din Manchester Guardian, din 4 iunie 1924, ,a fost unul dintre puținele prânzuri la care oaspeții arătau mai distinși decât chelnerii” o întâlnire interesantă și specific londoneză. John Galsworthy, în calitate de președinte, și-a exprimat omagiile față de Regina Maria și a vorbit despre receptarea pieselor lui Čapek în Anglia. Acesta din urmă a mulțumit într-o engleză simplă și directă, pe care o învățase, conform mărturisirii sale, cu ajutorul lexiconului, dar probând o pronunție clară și corectă.

Regina Maria nu s-a adresat auditoriului, ceea ce nu înseamnă că încărcătura emoțională a momentului - s-ar putea invoca aici reflecțiile lui Paul Ricouer asupra diferenței dintre termenii aristotelieni mnèmē și anamnēsis - nu a fost capturată de secretarul P.E.N. Club-ului Român. Conștientizând semnificația strategică a momentului, Emanoil Bucuța și-ar fi

${ }^{10}$ Čapek și-a publicat impresiile în Letters from England/Scrisori din Anglia, Praga 1937. 
dorit multiplicarea acestuia - „Ar trebui refăcută poate acea clipă, cu Regina prezidând o masă a PEN-Clubului român și cu un oaspe de departe la dreapta ei” (Bucuța, 1934: 289).

Confirmarea faptului că totul fusese un succes o avem și într-o scrisorică din 7 iunie 1924, în care ambasadorul României la Londra se adresa secretarei executive a P.E.N Club-ului englez - „Stimată Domnișoară Scott/ Trebuie să vă felicit încă o dată pentru reuşita prânzului organizat la Pen Club, de care Majestatea Sa Regina a fost foarte mulțumită./.../Al dumneavoastră sincer,/ Nicolae Titulescu" (Titulescu, Arhiva P.E.N International).

\section{Concluzii}

Din România însă, Emanoil Bucuța nu avea resursele de a gestiona la acest nivel relațiile și demersurile care se impuneau. Îi revenea lui Marcu Beza o asemenea sarcină, de a continua de fapt ceea ce el însuși declanșase, cu doi ani înainte. Întors la Londra după expediția americană, consulul și-a reluat activitatea diplomatică oficială, în care calitate nu contenea să speculeze, în favoarea României, desigur, relațiile întemeiate în atât de diverse împrejurări.

Un clip de presă din The Daily Graphic, de pildă, din toamna târzie a aceluiași an 1924, ni-l arată pe Marcu Beza ca amfitrion al unei petreceri la care doi dintre invitați ascultă ca în transă Marșul Funebru al lui Chopin, în jurul orei două noaptea. Interpretarea îi aparține unui alt invitat, excentricul „Mișu, cel mai puțin convențional dintre tenismeni”, probabil Nicolae Mișu, jucător de tenis și diplomat ${ }^{11}$ (Arhiva Marcu Beza, 3802).

$\mathrm{Nu}$ era singurul invitat excentric, după cum observă autorul articolașului. „Marco Beza și frumoasa lui soție” erau „profund pasionați de muzică”, drept urmare printre cei solicitați să onoreze recepția se număra și Buica, ,violonistul care a concertat în fața Reginei României la Londra și la București”'12 (Arhiva Marcu Beza, 3802). Interpretarea de către acesta din urmă a Ciocârliei a fost „o adevărată simfonie a pădurii în primăvară" (Arhiva Marcu Beza, 3802).

Cât despre cei doi înmărmuriţi spectatori mai sus pomeniți, unul era Jules Romains și celălalt Mme Jo van Ammers ${ }^{13}$. În finalul textului se menționează că „Jules Romains și Dl. Beza au devenit prieteni după ce s-au

\footnotetext{
${ }^{11}$ Câștigător al turneului de la Monte Carlo în 1919, Nicolae Mişu a reprezentat România la Olimpiada de la Paris din 1924 și a fost component al echipei de Cupa Davis a țării noastre.

12 Descendent al unei vechi familii de lăutari din județul Olt, Nicolae Buică (1855-1932) și-a început studiile muzicale la Conservatorul din București și le-a desăvârșit la Conservatorul din Paris. La Londra a avut un angajament la Palladium Theatre.

${ }^{13}$ Numele complet este Johanna van Ammers-Küller. Prolifică prozatoare olandeză şi una dintre cele mai populare scriitoare europene din perioada interbelică, avea totuși să sufere consecințele, după cel de al Doilea Război Mondial, orientării ei pro-germane.
} 
cunoscut la întâlnirea P.E.N. de la New York" (Arhiva Marcu Beza, 3802). Atât Marcu Beza cât și Emanoil Bucuța vedeau în Jules Romains un prieten al României, înainte de toate. Dar, pe măsură ce dimensiunea de activism politic a organizației se accentua, unele zone își pierdeau din claritatea inițială. „Uneori a fost nevoie și de scrisori deschise”, recunoștea Bucuța în articolul său jubiliar, „ca aceea către Jules Romains.” (Bucuța, 1934: 291) Încărcătura politică a acelui document va constitui însă obiectul unui viitor articol, .

\section{References:}

A Solemn Hour \& Seeing Through the Skin, 8 nov. 1924, clip de presă din The Daily Graphic. București: Arhiva Marcu Beza - Muzeul Colecțiilor de Artă.

Bradbrook, B.R. (1960). Letters to England from Karel Čapek. In The Slavonic and East European Review, Vol. 39, No. 92 (Dec. 1910), 61-72.

Bucuța, E. (1934) P.E.N. CLUBUL ROMÂN / THE ROMANIAN P.E.N. CLUB. In Boabe de Grâu, (Anul V), nr. 5, 284-300.

Bucuța, E. (1924) Scrisori către Marcu Beza / Letters to Marcu Beza - 26 ianuarie, 19 iulie 1924. București: Arhiva Marcu Beza, Muzeul Colecțiilor de Artă.

Cârneci, M. (2017). PEN Internațional - PEN România la aniversare / Romanian PEN Club Anniversary, In Observator Cultural. https://www.observatorcultural.ro/articol/pen-international-pen-romania-laaniversare/. Accesat la 12.05.2017.

Lawn, M. (ed.) (2009) Modelling the Future: exhibitions and the materiality of education. Oxford: Symposium Books Ltd.

Pârvan, V. (1924) Scrisoare către Marjorie Scott / Letter to Marjorie Scott, 30 aprilie 1924, Arhiva P.E.N. International.

Popescu, D.H. (2019) Pentru o istorie a P.E.N. Club-ului Român: 1 / For a History of the Romanian PEN Club: 1. In Journal of Humanistic and Social Studies, Volume 10, No 1, 63-74.

Popescu, D.H. (2019) Pentru o istorie a P.E.N. Club-ului Român: 2 / For a History of the Romanian PEN Club: 2. In Analele Universității din Oradea. Fascicula Limba și Literatura Română, 203-215.

Protopopescu, D. (1924) Scrisoare către Marjorie Scott / Letter to Marjorie Scott, 1 decembrie 1924, Arhiva P.E.N. International.

R., L. (1923) P.E.N., 16 noiembrie 1923, clip de presă, sursă neidentificată. București: Arhiva Marcu Beza, Muzeul Colecțiilor de Artă.

Titulescu, N. (1924) Scrisoare către Marjorie Scott / Letter to Marjorie Scott, 7 iunie 1924, Arhiva P.E.N. International. 